\title{
The Trade Structure of the Total Manufactured Goods: A New Perspective of Research on the RMB Real Exchange Rate Model
}

\author{
Zhu Zhi-ming ${ }^{1}$, Wu Jin-ya ${ }^{2}$, Chen Tao $^{3} \&$ He Bing-yan ${ }^{1}$ \\ ${ }^{1}$ Business School, Hohai University, Nanjing, China \\ ${ }^{2}$ Goulian Securities, Wuxi, China \\ ${ }^{3}$ School of Management \& Engineering, Nanjing University, Nanjing, Jiangsu, China \\ Correspondence: Zhu Zhi-ming, Business School, Hohai University, West Focheng Road No.8, Jiangning \\ District, Boxue building, Nanjing, Jiangsu province, 11106, China. E-mail: zhimingzhu@126.com
}

Received: April 25, 2014

Accepted: May 8, 2014

Online Published: June 25, 2014

doi:10.5539/ijef.v6n7p127

URL: http://dx.doi.org/10.5539/ijef.v6n7p127

\begin{abstract}
Different from the traditional researches only focus on the relationship between the real exchange rate and trade balance, terms of trade, gross domestic product. This paper led the relevance between real exchange rate and trade structure Balassa-Samuelson effect. From the perspective of the total manufactured goods trade structure, an empirical study was done with annual data 1981-2012 by co-integration technique. The results showed that China's total trade structure had the co-integration relationship with the real exchange rate, and it had a more obvious effect on the incidence and model fitting. So four basic economic factors were chosen which were the variables of aggregate trade structure, trade conditions, openness, monetary supply, these constructed RMB equilibrium real exchange rate estimation model. It would give theoretical supports to exploration of RMB real exchange rate.
\end{abstract}

Keywords: manufactured goods, total trade structure, RMB, real exchange rate, BEER model

\section{Introduction}

In recent years, domestic and foreign scholars have been much research on relationships between the real exchange rate and various economic variables. Balassa (1964) and Samuelson (1964) firstly put forward the famous Balassa-Samuelson hypothesis. The B-S effect soon became a basic theoretical framework of research on the relationship between the real exchange rate and economic growth. Later, many international scholars had the empirical test on kinds of propositions it contained. Considering the similar study abroad, Hsieh (1982), after introducing the wage rate variable, found Balassa-Samuelson effect on the real exchange rate and productivity differences obviously. Edison and Klovland (1987), through the study of the pound and the Norwegian krone, found that the real exchange rate movements were influenced by the productivity growth gap between the two countries. On the basis of the dynamic equilibrium model, Asea and Mendoza (1994) had a test on the Balassa-Samuelson effect for the first time. Strauss (1995), Strauss (1996), Kawai (1997) proved that a national exchange rate had a significant effect of B-S. Zussman (2001) introduced the technology of infiltration mechanism, he found that in different periods, the non-traded goods sector in different countries had the same productivity growth rate, therefore productivity catch-up effect of trade goods sector would cause the real exchange rate rise. Ordonez (2009) found that the competitiveness of the traded goods sector was mainly shown in the real exchange rate, and the real exchange rate played a decisive role in Spain's salary.

In domestic research, Yu Meng (2001), firstly used Balassa-Samuelson effect to study Asian countries and the actual situation of China's exchange rate movements, found that after the 1990's, China's exchange rate system, RMB real exchange rate and economic growth had a certain B-S effect. Wang Wei (2003), Lu Feng (2006), E Yongjian and Ding Jianping (2007) did research on the relationship between the real exchange rate and multiple factors respectively.

Throughout these studies, most of them focused on the relationship between the real exchange rate and trade balance, terms of trade, GDP etc., few focused on the relationship between the real exchange rate fluctuation and trade structure. In fact, it is not comprehensive enough to only concentrate on the economic factors while ignoring the trade structure. To a certain extent, a country's trade structure change, can reflect the change of 
traded goods sector productivity, then it influences its real exchange rate. Throughout China's trade structure change in recent decades, the share of manufactured goods increased significantly, and the manufactured goods production department has a higher productivity level and technical content. Therefore, this article aims to use Balassa-Samuelson effect to analyze if a country's total manufactured goods trade structure change will promote the real exchange rate, and build RMB equilibrium exchange rate model, in order to provide theoretical basis for a reasonable judgment of RMB equilibrium exchange rate and policy suggestions.

\section{A New Perspective of RMB Exchange Rate Analysis-Manufactured Goods Trade Structure}

\subsection{The Same Tropism between RMB Exchange Rate and Total Trade Structure}

Based on the perpetual reform of China's foreign trade system, China's trade structure is also constantly changing. According to the definition of The United Nations' "the standard international trade classification", manufactured goods, this paper defines the total trade structure as the share of manufactured goods in the aggregate sum of import and export trade. According to data from 1981 to 2012, RMB nominal exchange rate (direct quotation) and the change of the total trade structure numerical graphics are shown in Figure 1.

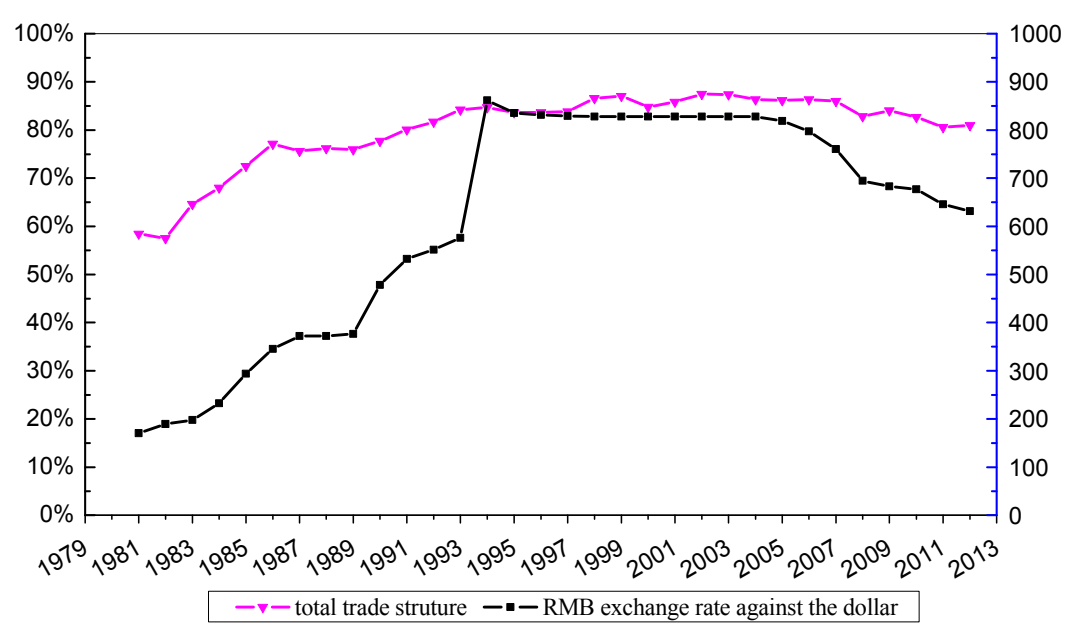

Figure 1. RMB exchange rate and the changing trend of total trade structure from 1981 to 2012

Note. RMB exchange rate : yuan /100 dollar.

According to Figure 1, we make assumptions as follows: There may be geometrical tropism between RMB nominal exchange rate (direct quotation) and the trade structure.

\subsection{The Demonstration of the Relationship between Total Trade Structure and RMB Real Exchange Rate}

To analyze the relationship between the total trade structure and RMB real exchange rate, according to the Balassa-Samuelson effect, establish econometric model as follows:

$$
\ln \text { reer }=\alpha+\beta \ln t t s+\varepsilon
$$

Among them, reer is RMB real exchange rate (Note 1). tts means manufactured goods trade structure, $\alpha$ is the constant term, $\varepsilon$ is the random error term, $\beta$ is the variable.

Table 1. RMB real exchange rate and data of trade structure from 1981 to 2012

\begin{tabular}{cccccc}
\hline year & Real exchange rate $($ reer $)$ & Total trade structure $(t t s)$ & year & Real exchange rate $($ reer $)$ & Total trade structure $(t t s)$ \\
\hline 1981 & 280.306 & $58.45 \%$ & 1997 & 108.941 & $83.83 \%$ \\
1982 & 267.588 & $57.50 \%$ & 1998 & 114.712 & $86.59 \%$ \\
1983 & 263.055 & $64.63 \%$ & 1999 & 108.486 & $87.03 \%$ \\
1984 & 234.487 & $67.99 \%$ & 2000 & 108.54 & $84.78 \%$ \\
1985 & 198.943 & $72.53 \%$ & 2001 & 113.198 & $85.86 \%$ \\
1986 & 144.839 & $77.09 \%$ & 2002 & 110.573 & $87.47 \%$ \\
1987 & 125.461 & $75.63 \%$ & 2003 & 103.322 & $87.36 \%$ \\
1988 & 136.808 & $76.19 \%$ & 2004 & 100.546 & $86.33 \%$ \\
\hline
\end{tabular}




\begin{tabular}{lccccc}
\hline 1989 & 158.299 & $75.97 \%$ & 2005 & 100 & $86.16 \%$ \\
1990 & 116.005 & $77.70 \%$ & 2006 & 101.578 & $86.36 \%$ \\
1991 & 103.323 & $80.07 \%$ & 2007 & 105.616 & $85.99 \%$ \\
1992 & 99.102 & $81.72 \%$ & 2008 & 115.393 & $82.82 \%$ \\
1993 & 105.477 & $84.22 \%$ & 2009 & 119.843 & $84.01 \%$ \\
1994 & 82.658 & $84.70 \%$ & 2010 & 120.975 & $82.7 \%$ \\
1995 & 92.073 & $83.66 \%$ & 2011 & 126.780 & $80.6 \%$ \\
1996 & 101.189 & $83.66 \%$ & 2012 & 129.770 & $80.98 \%$ \\
\hline
\end{tabular}

Note. total trade structure is equal to the proportion of manufactured goods in the total volume of trade, the original data source: China statistical yearbook 2000-2012; real effective exchange rate replaces the real exchange rate for the base period of 2005, the data source: the IMF IFS (International Financial Statistics) database.

Because instability of time series may lead to a fake regression phenomenon, to avoid that, try to use co-integration techniques to establish the stable relationship between the two factors. Using the Engle and Granger (1987) the co-integration theory of E-G two-step method to test whether there is co-integration relationship between the real exchange rate and the total trade structure.

First of all, use the ADF test methods respectively to check $\ln$ reer and $\ln t t s$, as shown in Figure 2 and Figure 3.

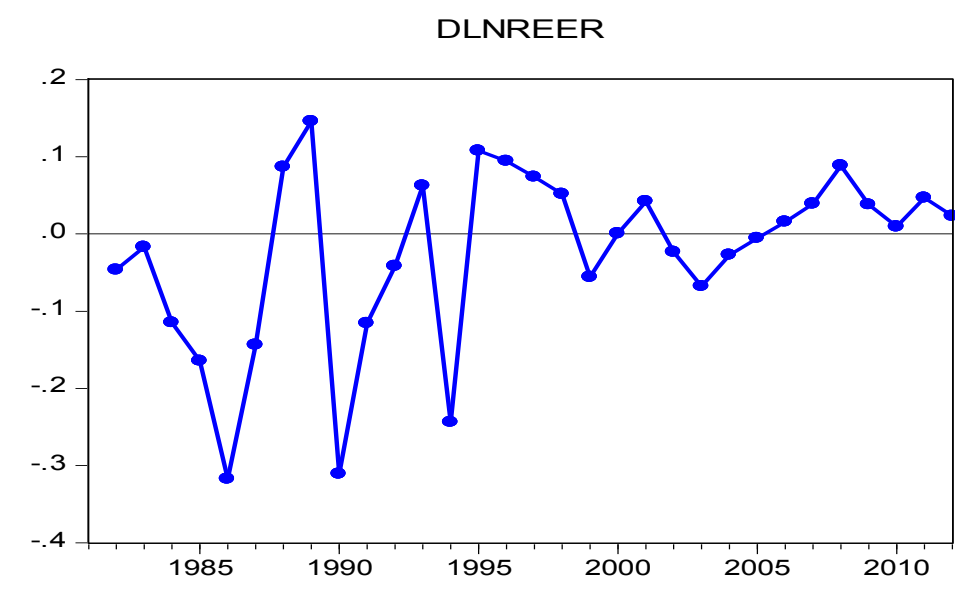

Figure 2. the first difference of the log to RMB real exchange rate

DLNTTS

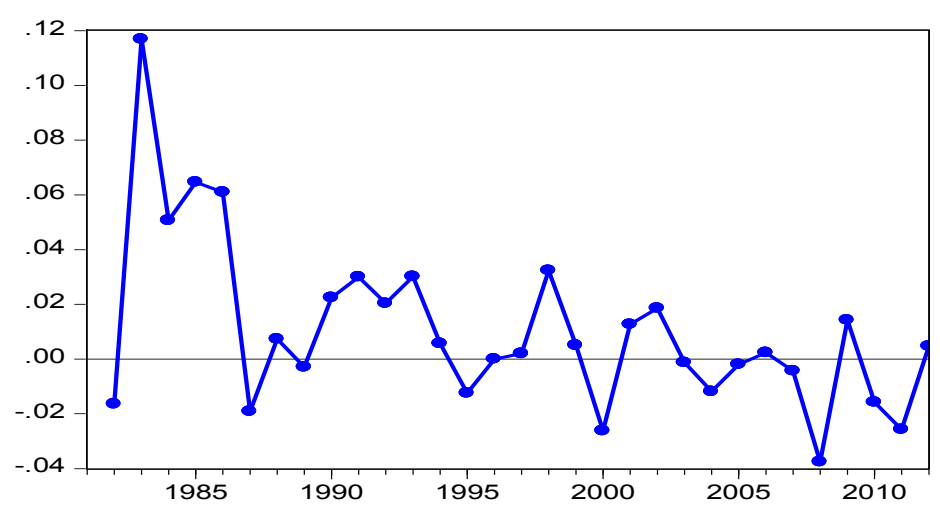

Figure 3. The first difference of the log to total trade structure 
Test results are shown in Table 2:

Table 2. The ADF test results of the view on total trade structure

\begin{tabular}{|c|c|c|c|c|c|c|}
\hline variable & test method (C T P) & ADF test value & $\begin{array}{c}\text { critical value } \\
1 \% \text { level }\end{array}$ & $\begin{array}{c}\text { critical value } \\
5 \% \text { level } \\
\end{array}$ & $\begin{array}{c}\text { critical value } \\
10 \% \text { level }\end{array}$ & (smooth steady) \\
\hline lnreer & $(\mathrm{C}$ T 0$)$ & -1.534936 & -4.284580 & -3.562882 & -3.215267 & not \\
\hline Dlnreer & $\left(\begin{array}{lll}\mathrm{C} & 0 & 0\end{array}\right)$ & $-4.225600^{*}$ & -2.644302 & -1.952473 & -1.610211 & yes \\
\hline $\operatorname{lntts}$ & (C T 6) & -1.050874 & -4.374307 & -3.603202 & -3.238054 & not \\
\hline Dlntts & $\left(\begin{array}{llll}C & 0 & 0\end{array}\right)$ & $-3.742968 *$ & -2.644302 & -1.952473 & -1.610211 & yes \\
\hline
\end{tabular}

Note. (1) lnreer means the log to RMB real exchange rate; ln tts means the log to total trade structure. C, T, P respectively mean constant term, time trends and lag order number, the selection of the best lag order number is based on AIC and SC minimum principle. D is the first difference. (2) * means to decline the original assumption under $1 \%$ significance level. ** means to decline the original assumption under $5 \%$ significance level. $* * *$ means to decline the original assumption under $10 \%$ significance level.

The Table 2 shows that the original variables of RMB real exchange rate and total trade structure index are not stationary series, but their first order difference is stable under $1 \%$ significance level. It means that they are all first order single integer sequence, which meets the requirements of Engle Granger co-integration test, the two factors may have a co-integration relationship.

The second step, using an ordinary least-squares regression method to test variable lnreer and $\ln t t s$, regression results are shown in Table 3:

Table 3. The regression results of the view on total trade structure

\begin{tabular}{lllll}
\hline Variable & Coefficient & Std. Error & t-Statistic & Prob. \\
\hline LNTTS & -2.724808 & 0.194287 & -14.02464 & 0.0000 \\
C & 4.219858 & 0.049125 & 85.90120 & 0.0000 \\
R-squared & 0.867661 & Mean dependent var & 4.842300 \\
Adjusted R-squared & 0.863250 & S.D. dependent var & 0.322135 \\
S.E. of regression & 0.119125 & Akaike info criterion & -1.356833 \\
Sum squared resid & 0.425720 & Schwarz criterion & -1.265224 \\
Log likelihood & 23.70932 & Hannan-Quinn criter. & -1.326467 \\
F-statistic & 196.6906 & Durbin-Watson stat & 0.941209 \\
Prob(F-statistic) & 0.000000 & &
\end{tabular}

Co-integration relationship is as follows:

$$
\text { LNREER }=-2.72480798261 * \text { LNTTS }+4.21985799715
$$

$$
(-14.02464) \quad(85.90120)
$$

Using a regression model to estimate the residual sequence $e$, do stationarity test with $e$, then has the Granger causality test with the co-integration correlations (2). Granger test results as shown in Table 4

Table 4. The granger test results of the view on total trade structure

\begin{tabular}{llll}
\hline Null Hypothesis: & Obs & F-Statistic & Prob. \\
\hline LNTTS does not Granger Cause LNREER & 31 & 5.43469 & 0.0272 \\
LNREER does not Granger Cause LNTTS & & 0.02340 & 0.8795 \\
\hline
\end{tabular}

Depending on Table 4, under the confidence level of $5 \%$, the trade structure is the Granger cause of the real exchange rate, while the real exchange rate is not Granger cause of the total trade structure. To a certain extent, since the aggregate trade structure can be used to explain the movements of RMB real exchange rate, so the total trade structure will be added to the estimation model of RMB real exchange rate. 


\section{Construction of RMB Real Exchange Rate Model under the Perspective of the Total Trade Structure}

\subsection{Choice of Model}

Domestic and overseas scholars mainly adopt five basic models in the study of Equilibrium Exchange rate: Purchasing Power Parity, the PPP; the Basic Fundamental Equilibrium Exchange Rates, FEER; Natural Real Exchange Rates, NATREX; Equilibrium Real Exchange Rates, ERER; Behavioural Equilibrium Exchange Rates, BEER. Dou Xiangsheng (2006) argued that because the BEER model only involved single equation which had more maneuverability compared with other types of equilibrium exchange rate calculation model. What's more, BEER model included econometric analysis of the behavior of the real exchange rate directly, and explained the actual behavior of the exchange rate through the relevant economic variables which had an impact on itself, there was good explanatory power in the empirical aspects. In recent years, BEER model has been widely used in calculation of equilibrium real exchange rate, and BEER model has further advantages over the study on misaligned exchange rates in the developing countries: though in the developing countries, there may be some problems in the empirical analysis such as the sample size is not big enough, data quality is not high and economic structure is not stable. But Wang Chen (2006) put forward that the results of model analysis of BEER were often able to predict when the real exchange rate and fundamental variables had the co-integration relationship. Furthermore, the co-integration equation often could reproduce some exchange rate misalignments. On this basis, under the perspective of the trade structure of the total manufactured goods, this article also uses the BEER model to build RMB real exchange rate estimation model.

Li Kun (2010) believed that BEER model simulated a set of long-term factors which could play a key role on the real exchange rate and the correlation. This article tries to use the long-term equilibrium method to find the equilibrium exchange rate. The contracted model expression is:

$$
q_{t}=\beta^{\prime} X_{t}+\tau^{\prime} T_{t}+\varepsilon_{t}
$$

Among them, $X_{t}$ means the basic economic factor which influences the exchange rate in the medium to long term, $\mathrm{Tt}$ is a short-term factor, $\varepsilon_{\mathrm{t}}$ is a random perturbation term.

\subsection{The Determination and Analysis of Basic Factors in the Model}

To a great extent, BEER emphasizes its empirical significance. The application depends on the choice of proper theoretical guidance of the basic economic factors. Based on the importance of variable selection, this paper mainly refers to Xu Sixing' s (2009) analysis of Montiel, which meant the equilibrium exchange rate was affected by supply and demand, the external environment and business policies. Firstly, domestic supply factors, especially the productivity growth of traded goods sector is faster than the non-traded sector, which will cause Lhasa - the Samuel effect; The second is the demand factors, such as the money supply, the government expenditure in terms of traded goods and untraded goods; the third is the movements of the international economic environment, such as the trade conditions, the foreign economic flow and the international inflation, etc. The fourth is the economic liberalization policies, such as import and export tariffs, export subsidies and dual exchange rate, etc. Considering the four categories above, we select suitable basic factors as follows:

First of all, the current research, generally considered that the term of trade was the most important basic economic factors which affected long-term equilibrium exchange rate (Zhang Xiaopu, 1999; Zhang Xiaopu, 2000; Lin Bojiang, 2002). The term of trade is the export price index/the import price index ratio, if the term of trade rises, means the improvement of trade environment; the term of trade deteriorates conversely. In the long run, when the term of trade improves, current account will improve, and then demands the appreciation of equilibrium exchange rate in order to maintain the balance of Current Account; On the other hand, the deterioration of trade term, will demand the depreciation of equilibrium exchange rate. So we choose the term of trade as one of the fundamental factors in our model.

What's more, according to the study of Shi Jianhuai and Yu Haifeng (2005), Wang Weiguo and Huang Wanyang (2005), Chen Hao (2008), openness affects adversely on equilibrium exchange rate, if there is no corresponding devaluation, openness in the developing world is generally difficult to maintain, in other words, compared with the trade control, it causes further currency devaluation in the case of trade liberalization. Therefore, choose openness as another factor. In this survey, openness is the sum import and export / GDP ratio.

Finally, according to the Lin Bojiang (2002), we found that the broad money supply was correlated with RMB real exchange rate. When the broad money supply (M2) expands, the rate of inflation will rise, the real exchange rate will appear to rise, the balance of the country's current account will deteriorate. In order to maintain the sustainability of the external balance, it will demand the depreciation of the equilibrium exchange rate. Otherwise, M2 contracts, the equilibrium exchange rate will depreciate. Therefore, this survey will apply M2 as 
one of the fundamental factors.

In addition, when determining variables, not only must satisfy the requirements of the various aspects of the theory itself, but also ensure that the data can be available or estimated. At last, choose a few basic economic variables as follows: The total trade structure, terms of trade, openness and the money supply.

In conclusion, the model of RMB real exchange rate can be written as follows:

$$
\text { reer }=f\left(\mathrm{tts}^{-}, \text {tot }^{?}, \text { open }^{-}, r m 2^{?}\right)
$$

Among them,reer is the real exchange rate which is replaced by the real effective exchange rate, tts means trade structure, and tot as the term of trade, open is for openness, rm2is for money supply; the plus or minus in the top right corner of variable is a first order partial derivative symbols of the variable, means the changing direction of RMB equilibrium exchange rate when basic factors increase, while the question mark means uncertain, the relationship must be approved by the empirical test.

\section{Co-Integration Test and Analysis}

According to th relationship exists, it must be the dynamic error correction model describing the real exchange rate from thee actual behavior equilibrium exchange rate model, after determining the basic economic factors, can directly estimate the relationship of the real exchange rate and the basic variables. It tests the long-term equilibrium relationship of the real exchange rate and the basic variables through the co-integration techniques. If the co-integration deviation to the equilibrium. Finally, get the equilibrium of real exchange rate through the calculation of long-term equilibrium values of the basic economic factors.

\subsection{The Data Selection and Processing}

According to the above choice of economic variables, the sample interval of this article is annual data from 1981 to2012 which are shown in Table 5.

Data selection and processing of every economic variable are as follows: reer means real effective exchange rate data which are published by IMF. It is built on the year 2005, if the index rises, it means the appreciation of $\mathrm{RMB}$, while the index decreases, it means RMB depreciation.

tts: Trade structure is defined as manufactured goods value/the sum of import and export ratio.

tot: Term of trade is an indicator which is used to measure national profitability in a certain period, reflecting a country's foreign trade environment, the term of trade in this article, is the term of net commodity trade (NBTT) which is equal to export price index divides import price index*100\%, it can be approximately replaced by the ratio of total exports (ex) to total imports $(\mathrm{im})$, tot $=$ ex/im.

openness: Openness is equal to the sum of import and export dividends GDP.

$\mathrm{rm} 2: \mathrm{rm} 2=\mathrm{m} 2 *(1-\mathrm{CPI}) / \mathrm{GDP}, \mathrm{m} 2$ is the broad money supply, which is equal to money (the International Monetary Fund release) pluses quasi-money; CPI is for the consumer price index in China; GDP is the gross domestic product.

Table 5. Every economic variable data from 1981 to 2012

\begin{tabular}{cccccc}
\hline year & $\begin{array}{c}\text { Real exchange } \\
\text { rate (reer) }\end{array}$ & $\begin{array}{c}\text { Trade structure } \\
\text { (tts) }\end{array}$ & $\begin{array}{c}\text { Term of trade } \\
\text { (tot) }\end{array}$ & $\begin{array}{c}\text { openness } \\
\text { (open) }\end{array}$ & $\begin{array}{c}\text { Money supply } \\
\text { (rm2) }\end{array}$ \\
\hline 1981 & 280.306 & 0.584480 & 0.999637 & 0.150320 & 0.394605 \\
1982 & 267.588 & 0.574965 & 1.157428 & 0.144890 & 0.417529 \\
1983 & 263.055 & 0.646277 & 1.039084 & 0.144248 & 0.448141 \\
1984 & 234.487 & 0.679882 & 0.953630 & 0.166633 & 0.485255 \\
1985 & 198.943 & 0.725338 & 0.647307 & 0.229225 & 0.490408 \\
1986 & 144.839 & 0.770861 & 0.721191 & 0.251129 & 0.577697 \\
1987 & 125.461 & 0.756258 & 0.912556 & 0.255767 & 0.611721 \\
1988 & 136.808 & 0.761905 & 0.859629 & 0.254061 & 0.518314 \\
1989 & 158.299 & 0.759738 & 0.888367 & 0.244575 & 0.549798 \\
1990 & 116.005 & 0.777028 & 1.163952 & 0.297844 & 0.762101 \\
1991 & 103.323 & 0.800694 & 1.127275 & 0.331740 & 0.824853 \\
1992 & 99.102 & 0.817194 & 1.054042 & 0.338723 & 0.845743 \\
1993 & 105.477 & 0.842230 & 0.882502 & 0.318985 & 0.861374 \\
\hline
\end{tabular}




\begin{tabular}{lccccc}
\hline 1994 & 82.658 & 0.847037 & 1.046638 & 0.422880 & 0.738882 \\
1995 & 92.073 & 0.836569 & 1.126404 & 0.386551 & 0.828315 \\
1996 & 101.189 & 0.836602 & 1.087983 & 0.339069 & 0.980370 \\
1997 & 108.941 & 0.838318 & 1.283922 & 0.341474 & 1.130709 \\
1998 & 114.712 & 0.865910 & 1.309990 & 0.318116 & 1.260683 \\
1999 & 108.486 & 0.870263 & 1.176416 & 0.333376 & 1.368651 \\
2000 & 108.54 & 0.847777 & 1.107106 & 0.395841 & 1.364882 \\
2001 & 113.198 & 0.858568 & 1.092567 & 0.384693 & 1.416414 \\
2002 & 110.573 & 0.874653 & 1.103080 & 0.426968 & 1.482396 \\
2003 & 103.322 & 0.873587 & 1.061702 & 0.518937 & 1.534948 \\
2004 & 100.546 & 0.863310 & 1.057191 & 0.597574 & 1.457179 \\
2005 & 100 & 0.861629 & 1.154556 & 0.632224 & 1.502767 \\
2006 & 101.578 & 0.863640 & 1.224237 & 0.651697 & 1.573727 \\
2007 & 105.616 & 0.859875 & 1.273890 & 0.627290 & 1.444928 \\
2008 & 115.393 & 0.828206 & 1.263236 & 0.572915 & 1.423782 \\
2009 & 119.843 & 0.840123 & 1.194537 & 0.442423 & 1.804653 \\
2010 & 120.975 & 0.827125 & 1.130132 & 0.502406 & 1.748135 \\
2011 & 126.780 & 0.806253 & 1.089069 & 0.499918 & 1.703608 \\
2012 & 129.77 & 0.809809 & 1.126654 & 0.470496 & 1.828362 \\
\hline
\end{tabular}

Note. The original data of reer and $\mathrm{m} 2$ are from IFS database (from the IMF International Financial Statistics), the rest are from China statistical yearbook 2000-2013.

To overcome the heterhoskedasticity of the time sequence, we need to get the trend of linearization, then take the $\log$ to each variable, mark as lnreer, lntts, lntot, lnopen and lnrm2.

\subsection{Stationarity Test of Data}

The standard method of stationarity test is unit root test. According to the definition of co-integration, if there is a co-integration relationship between time series, they must be the same order sheet. In this paper, use the ADF test in the unit root test which is shown in Table 6:

Table 6. The ADF test results of the basic factors variables

\begin{tabular}{|c|c|c|c|c|c|c|}
\hline variable & $\begin{array}{l}\text { test method } \\
\text { (C T P) }\end{array}$ & $\mathrm{ADF}$ test value & $\begin{array}{c}\text { critical value } \\
1 \% \text { level }\end{array}$ & $\begin{array}{c}\text { critical value } \\
5 \% \text { level }\end{array}$ & $\begin{array}{c}\text { critical value } \\
10 \% \text { level }\end{array}$ & $\begin{array}{c}\text { conclusion } \\
\text { (smooth steady) }\end{array}$ \\
\hline lnreer & $(\mathrm{C}$ T 0$)$ & -1.534936 & -4.284580 & -3.562882 & -3.215267 & not \\
\hline Dlnreer & $\left(\begin{array}{lll}\mathrm{C} & 0 & 0\end{array}\right)$ & -4.225600 & -2.644302 & -1.952473 & -1.610211 & yes \\
\hline $\operatorname{lntts}$ & $(\mathrm{C} \mathrm{T} 6)$ & -1.050874 & -4.374307 & -3.603202 & -3.238054 & not \\
\hline Dlntts & $\left(\begin{array}{lll}C & 0 & 0\end{array}\right)$ & -3.742968 & -2.644302 & -1.952473 & -1.610211 & yes \\
\hline lntot & $\left(\begin{array}{lll}\mathrm{C} & 0 & 0\end{array}\right)$ & -2.29382 & -3.66166 & -2.96041 & -2.61916 & not \\
\hline Dlntot & $\left(\begin{array}{lll}\mathrm{C} & 0 & 0\end{array}\right)$ & -2.29382 & -3.66166 & -2.96041 & -2.61916 & yes \\
\hline lnopen & $(\mathrm{C}$ T 0$)$ & -5.38627 & -3.67017 & -2.96397 & -2.62101 & not \\
\hline Dlnopen & $\left(\begin{array}{lll}C & 0 & 0\end{array}\right)$ & -1.50823 & -4.28458 & -3.56288 & -3.21527 & yes \\
\hline $\operatorname{lnrm} 2$ & $(\mathrm{C}$ T 1) & -4.61341 & -3.67017 & -2.96397 & -2.62101 & not \\
\hline Dlnrm2 & $\left(\begin{array}{lll}C & 0 & 1\end{array}\right)$ & -2.48275 & -4.29673 & -3.56838 & -3.21838 & yes \\
\hline
\end{tabular}

Note. (1) (C, T, P) C, T, P respectively means in the constant term, time trend item and lagging order number, the optimal selection of the lag order is determined by the AIC and SC minimum principle. D means the first order difference. $(2) *$ means to decline the original assumption under $1 \%$ significance level. ${ }^{* *}$ means to decline the original assumption under $5 \%$ significance level. $* * *$ means to decline the original assumption under $10 \%$ significance level.

In the ADF test, the test results show that the original sequence of the real exchange rate (lnreer), the term of trade (lntot), trade structure (lntts), openness (lnopen), money supply (lnrm2) are bigger than the critical value under the $5 \%$ significant level. It means that the unit root is accepted in original hypothesis, the original sequences are not stationary series.

In $\mathrm{ADF}$ test, while first order difference sequence dlnreer, dlntot, dlntts, dlnopen, dlnrm2 is less than the critical value of the $5 \%$ significant level, we reject the original hypothesis, first order difference sequence of the original 
variables are stationary series. Therefore $\operatorname{lnreer}$, lntts, lntot, lnopen and $\ln r m 2$ are single integer sequence, they can have co-integration test.

\subsection{Co-Integration Test}

From the object of co-integration test, co-integration test can be divided into 2 kinds. One is E-G two-step which is on the basis of regression residual. It was proposed by Engle and Granger (1987). Nowadays, the method is applied in the test of co-integration relationship between two variables. Another is Johansen test which is on the basis of regression coefficient. It was proposed by Johansen and Juselius (1990), it is also called JJ test, which is a good method for multivariate co-integration test.

Because the Johansen test is very sensitive to lag phase, firstly we must determine the lag order number of co-integration model of equilibrium real exchange rate. We determine the VAR model and Johansen test lag according to unconstrained VAR model, the lag order number of the Johansen test $=$ lag order number- 1 of the VAR model. Then assume that maximum lag period is for three phases, which are based on the selection criteria of lag VAR model, LR, FPE, AIC and HQ statistics are 3 periods (Table 7), thus determine the lag order number of the VAR model is stage 3, the lag order number of co-integration test is phase 2 . When choosing the co-integration model of the real exchange rate, we need to select co-integration model which contains an intercept term except the time trend term.

Table 7. The test results of lag period

\begin{tabular}{ccccccc}
\hline Lag & LogL & LR & FPE & AIC & SC & HQ \\
\hline 0 & 102.6865 & NA & $8.16 \mathrm{e}-10$ & -6.736999 & -6.501258 & -6.663168 \\
1 & 214.8149 & $177.8588^{*}$ & $2.07 \mathrm{e}-12^{*}$ & -12.74585 & $-11.33141^{*}$ & $-12.30287^{*}$ \\
2 & 239.4002 & 30.51970 & $2.52 \mathrm{e}-12$ & -12.71725 & -10.12411 & -11.90511 \\
3 & 270.8669 & 28.21152 & $2.64 \mathrm{e}-12$ & $-13.16323^{*}$ & -9.391382 & -11.98194 \\
\hline
\end{tabular}

* indicates lag order selected by the criterion

LR: sequential modified LR test statistic (each test at 5\% level)

FPE: Final prediction error

AIC: Akaike information criterion

SC: Schwarz information criterion

HQ: Hannan-Quinn information criterion

The results of Johansen Co-integration test are shown in Table 8.

Table 8 . The test results of the tracing to characteristic root

\begin{tabular}{lllll}
\hline Hypothesized & \multicolumn{5}{l}{ Trace } & 0.05 \\
\hline No. of CE(s) & Eigenvalue & Statistic & Critical Value & Prob.** \\
None * & 0.788484 & 96.35463 & 69.81889 & 0.0001 \\
At most 1 & 0.518591 & 49.75093 & 47.85613 & 0.0328 \\
At most 2 & 0.434392 & 27.81980 & 29.79707 & 0.0831 \\
At most 3 & 0.240827 & 10.72419 & 15.49471 & 0.2290 \\
At most 4 & 0.078679 & 2.458408 & 3.841466 & 0.1169 \\
\hline Trace test indicates 2 cointegrating eqn(s) at the 0.05 level & \\
* denotes rejection of the hypothesis at the 0.05 level & \\
**MacKinnon-Haug-Michelis (1999) p-values \\
\hline
\end{tabular}

The test results show that under 5\% significance level, there is a long-term equilibrium relationship between lnreer, lntts, lntot, lnopen, lnrm2. The standardized coefficient of co-integration is shown in Table 9: 
Table 9. Standardized coefficient of co-integration

\begin{tabular}{lllll}
\hline Variable & Coefficient & Std. Error & t-Statistic & Prob. \\
\hline LNTTS & -2.968149 & 0.300632 & -9.873033 & 0.0000 \\
LNTOT & -0.447200 & 0.136708 & -3.271216 & 0.0029 \\
LNOPEN & -0.310712 & 0.098018 & -3.169940 & 0.0038 \\
LNRM2 & 0.410614 & 0.086432 & 4.750731 & 0.0001 \\
C & 3.875535 & 0.091046 & 42.56692 & 0.0000 \\
R-squared & 0.930304 & Mean dependent var & 4.842300 \\
Adjusted R-squared & 0.919979 & S.D. dependent var & 0.322135 \\
S.E. of regression & 0.091125 & Akaike info criterion & -1.810562 \\
Sum squared resid & 0.224203 & Schwarz criterion & -1.581541 \\
Log likelihood & 33.96900 & Hannan-Quinn criter. & -1.734648 \\
F-statistic & 90.09977 & Durbin-Watson stat & 1.082827 \\
Prob(F-statistic) & 0.000000 & & \\
\hline
\end{tabular}

$$
\text { LNREER }=-2.97 * \text { LNTTS }-0.45 * \text { LNTOT-0.31*LNOPEN }+0.410614 * \text { LNRM } 2+3.88
$$

Co-integration equation (5) indicates that not only there is a co-integration relationship between RMB real exchange rate and basic economic factors, but influencing direction is the basically consistent with the qualitative analysis of theoretical models: the improvement of total trade structure, the term of trade and openness will make RMB real exchange rate depreciation, which is negatively related to the real exchange rate; the actual RMB real exchange rate will rise when the money supply increases, the money supply is positively related to the real exchange rate. From the influence on the real exchange rate of variables, the elastic coefficient of trade structure to the real exchange rate is-2.97, namely the trade structure improving 1 point, the real exchange rate fell about 4.44 points; The elastic coefficient of the term of trade to the real exchange rate is- 0.45 , namely the terms of trade improve 1 point, the real exchange rate fell about 0.51 points; The elastic coefficient of Openness to the real exchange rate is -0.31 , namely openness improve 1 point, the real exchange rate fell about 0.53 points; The elastic coefficient of Real money supply to the real exchange rate is 3.88 , namely the money supply improve 1 point, real exchange rate improve approximately 0.85 point.

\section{Vector Error Correction Model (VEC) and Variance Decomposition Analysis}

\subsection{Vector Error Correction Model (VEC)}

Engle and Granger combined co-integration with error correction model, then the vector error correction model was established As long as there is a co-integration relationship between variables, error correction model can be deduced by an autoregressive distributed lag model. In the VAR model, each equation is an autoregressive distributed lag model. Therefore, VEC model can be seen containing co-integration, it is more convenient in building models of non-stationary time series which have a co-integration relationship between them. According to unconstrained VAR model, the lag period is three, then determine the lag period of VEC is 2 . According to the estimation results of the error correction model, we get the corresponding vector error correction model (estimate) as follows:

$$
\begin{aligned}
& D(\text { LNREER })=0.03 *(\operatorname{LNREER}(-1)+11.95 * \operatorname{LNTOT}(-1)-6.22 * \operatorname{LNOPEN}(-1)+14.15 * \operatorname{LNRM} 2(-1)-11.76)- \\
& 0.10 * \text { LNTTS(-1) + 0.59*LNTOT(-1) - 1.15*LNOPEN(-1) + 3.40*LNRM2(-1) - 0.99) - 0.47*D(LNREER(-1)) - } \\
& 0.31 * D(\operatorname{LNREER}(-2))-1.52 * D(\operatorname{LNTTS}(-1))-1.02 * D(\operatorname{LNTTS}(-2))+0.18 * D(\operatorname{LNTOT}(-1))-0.01 * D(\text { LNTOT(-2)) } \\
& -0.34 * D(\operatorname{LNOPEN}(-1))-0.10 * D(\operatorname{LNOPEN}(-2))-0.55 * D(\operatorname{LNRM} 2(-1))+0.17 * D(\operatorname{LNRM} 2(-2))+0.02
\end{aligned}
$$

Test on the stability of VEC model, because the model contains 4 unit root, so there are four root is equal to 1 (see Table 10), fell on the unit circle, all the rest roots fell within the unit circle (see Figure 4). In conclusion, vector error correction model is stable, the effect of model is better. 
Table 10. The data of the root to model AR

\begin{tabular}{ll}
\hline Root & Modulus \\
\hline 1.000000 & 1.000000 \\
1.000000 & 1.000000 \\
1.000000 & 1.000000 \\
1.000000 & 1.000000 \\
0.899027 & 0.899027 \\
$0.067378-0.746431 \mathrm{i}$ & 0.749466 \\
$0.067378+0.746431 \mathrm{i}$ & 0.749466 \\
$0.504491-0.516054 \mathrm{i}$ & 0.721681 \\
$0.504491+0.516054 \mathrm{i}$ & 0.721681 \\
$-0.238731-0.666470 \mathrm{i}$ & 0.707937 \\
$-0.238731+0.666470 \mathrm{i}$ & 0.707937 \\
$-0.065769-0.454333 \mathrm{i}$ & 0.459069 \\
$-0.065769+0.454333 \mathrm{i}$ & 0.459069 \\
-0.446933 & 0.446933 \\
-0.064632 & 0.064632 \\
VEC specification imposes 4 unit root(s) & \\
\hline
\end{tabular}

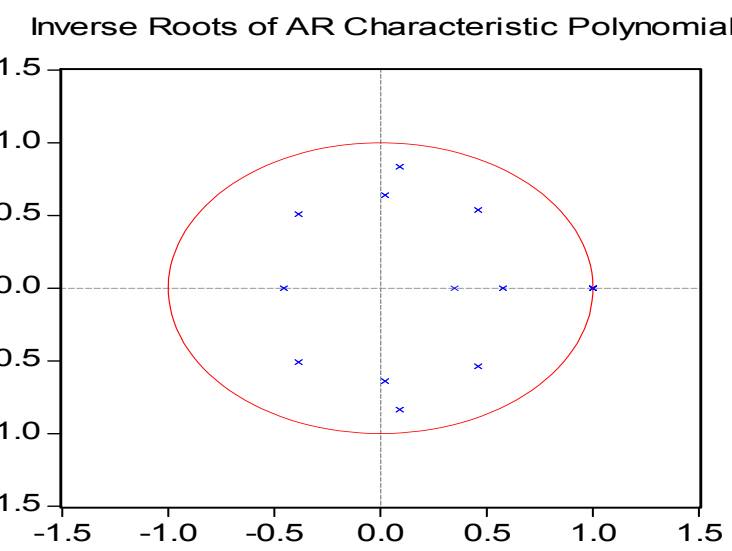

Figure 4. The graphics of the root to model AR

\subsection{Variance Decompose Analysis}

Variance decomposition is based on the analysis of each variable contribution to the endogenous variable changes (usually use variance to measure), evaluate the importance of different structural shocks. The basic idea of using variance decomposition analysis of the basic economic factors on the degree of contribution of the real exchange rate change. As shown in Table 11:

Table 11. The data of variance decomposition

\begin{tabular}{ccccccc}
\hline Period & S.E. & lnreer & lntts & lntot & lnopen & Lnrm2 \\
\hline 1 & 0.083926 & 100.0000 & 0.000000 & 0.000000 & 0.000000 & 0.000000 \\
2 & 0.117873 & 70.40494 & 14.76807 & 6.220200 & 0.966164 & 7.640633 \\
3 & 0.161716 & 40.68416 & 29.16844 & 11.72205 & 10.83299 & 7.592358 \\
4 & 0.200738 & 29.30454 & 40.12452 & 9.232351 & 15.83726 & 5.501327 \\
5 & 0.236063 & 22.65482 & 46.83045 & 7.533462 & 18.43818 & 4.543091 \\
6 & 0.268486 & 18.06609 & 47.91360 & 8.017191 & 21.30797 & 4.695145 \\
7 & 0.298592 & 15.36900 & 48.76353 & 8.468605 & 22.97430 & 4.424562 \\
8 & 0.329273 & 13.45271 & 50.75043 & 8.194956 & 23.79337 & 3.808544 \\
9 & 0.361165 & 11.77232 & 52.30319 & 8.052993 & 24.54417 & 3.327326 \\
10 & 0.393211 & 10.43293 & 53.37914 & 8.127529 & 25.02032 & 3.040073 \\
11 & 0.425573 & 9.326968 & 54.47584 & 8.116052 & 25.29848 & 2.782661 \\
\hline
\end{tabular}




\begin{tabular}{|c|c|c|c|c|c|c|}
\hline 12 & 0.458168 & 8.354585 & 55.41207 & 8.035425 & 25.67265 & 2.525270 \\
\hline 13 & 0.490094 & 7.554226 & 56.11146 & 7.974266 & 26.04846 & 2.311590 \\
\hline 14 & 0.521130 & 6.910939 & 56.70725 & 7.938526 & 26.30040 & 2.142888 \\
\hline 15 & 0.551673 & 6.366881 & 57.21958 & 7.917759 & 26.49856 & 1.997213 \\
\hline 16 & 0.581823 & 5.899295 & 57.65383 & 7.897451 & 26.68508 & 1.864344 \\
\hline 17 & 0.611479 & 5.500088 & 58.04884 & 7.869804 & 26.83512 & 1.746146 \\
\hline 18 & 0.640641 & 5.153406 & 58.40416 & 7.845089 & 26.95296 & 1.644383 \\
\hline 19 & 0.669320 & 4.847939 & 58.70984 & 7.827847 & 27.05844 & 1.555938 \\
\hline 20 & 0.697494 & 4.578822 & 58.97993 & 7.810739 & 27.15396 & 1.476550 \\
\hline 21 & 0.725144 & 4.340999 & 59.22433 & 7.791915 & 27.23786 & 1.404899 \\
\hline 22 & 0.752269 & 4.129560 & 59.44200 & 7.775548 & 27.31187 & 1.341027 \\
\hline 23 & 0.778880 & 3.940868 & 59.63623 & 7.762146 & 27.37683 & 1.283925 \\
\hline 24 & 0.805002 & 3.771600 & 59.81271 & 7.749511 & 27.43404 & 1.232140 \\
\hline 25 & 0.830652 & 3.618880 & 59.97355 & 7.737197 & 27.48541 & 1.184958 \\
\hline 26 & 0.855833 & 3.480608 & 60.11984 & 7.725855 & 27.53161 & 1.142086 \\
\hline 27 & 0.880557 & 3.355005 & 60.25341 & 7.715560 & 27.57297 & 1.103060 \\
\hline 28 & 0.904839 & 3.240450 & 60.37575 & 7.706007 & 27.61048 & 1.067320 \\
\hline 29 & 0.928690 & 3.135646 & 60.48808 & 7.697021 & 27.64480 & 1.034454 \\
\hline 30 & 0.952123 & 3.039528 & 60.59159 & 7.688613 & 27.67608 & 1.004193 \\
\hline
\end{tabular}

Up to 30 periods of data are given in above analysis results. Standard deviation of the basic economic factors rises with the increase of lag periods. Each variable has a continuous contribution to RMB real exchange rate. Among them, the real exchange rate, trade structure, the term of trade and openness have significant contributions to the variance decomposition of RMB real exchange rate. In the short-term, RMB real exchange rate itself has been the main contribution, then the influence of itself becomes weaker, ranging from the first term's $100 \%$ to the $30^{\text {th }}$ term's $3 \%$. The contribution of trade structure, term of trade and openness on real exchange rate change is rising, finally they respectively fix on $60.59 \%, 7.69 \%$ and $27.68 \%$. While the contribution of the money supply hit the peak $7 \%$ at stage 3 and 3 , then gradually fell back, eventually converge to $1 \%$.

\section{Conclusions}

This paper has established RMB real exchange rate estimation model under the perspective of the total trade structure. From the test results, the fit of the model is fine. The conclusion is consistent with the qualitative analysis. Based on the co-integration test, though the original sequences of RMB real exchange rate, trade structure, terms of trade, openness and money supply are not stable, their first order difference is stationary series, there is a long-term equilibrium relationship. On this basis, obtain co-integration equation between the several variables though Johansen test. Furthermore, vector error correction model is developed and the model is stable. Through the impulse response analysis, it is found that the movements of the basic economic factors have an effect on the pulse of the real exchange rate, the function of variance decomposition means the basic economic factors' contributions to real exchange rate changes. The contribution to exchange rate from big to small is: trade structure, openness, term of trade and the money supply. The model provides effective support to the estimation of RMB exchange rate theory.

\section{References}

Asea, P. K., \& Mendoza, E. G. (1994). The Balassa-Samuelson Model: A General-Equilibrium Appraisal. Review of International Economics, 3, 244-267.

Balassa, B. (1964). The Purchasing-Power Parity Doctrine: a Reappraisal. Journal of Political Economy, 6, 584596.

Chen, H. (2008). The Decision of RMB Equilibrium Exchange Rate: based on the test data from 1986 to 2006. Seeker, 10, 18-20.

Dou, X. S. (2006). Comments on Theories of Western Equilibrium Exchange Rate. Economic Review, 5, 47-152.

Edison, H. J., \& Klovland, J. T. (1987). A Quantitative Reassessment of the Purchasing Power Parity Hypothesis: Evidence from Norway and the United Kingdom. Journal of Applied Econometrics, 4, 309-330.

Engle, R. F., \& Granger, C. W. J. (1987). Co-Integration and Error Correction: Representation, Estimation, and Testing. The Econometric Society, 251-276. 
Er, Y., \& Ding, J. (2007). Weight difference in consumption, Productivity and Real Exchange Rate: a Dynamic General Equilibrium Model on the propagation of the Balassa-samuelson Hypothesis. World Economy, 3, $49-58$.

Hsieh, D. A. (1982). The Determination of the Real Exchange Rate: The Productivity Approach. Journal of International Economics, 12, 355-362.

Johansen, S., \& Juselius, K. (1990). Maximum Likelihood Estimation and Inference on Cointegration-with Applications to the Demand for Money. Oxford Bulletin of Economics and Statistics, 2, 169-210.

Kawai, M., \& Ohara, H. (1997). Nonstationarity of Real Exchange Rates in the G7 Countries:Are They Cointegrated with Real Variables. Journal of the Japanese and International Economics, 4523-4547.

Li, K. (2010). The Empirical Study of RMB Equilibrium Exchange Rate Based on the BEER Theory. Modern Business, 14, 37-39.

Lin, B. (2002). Estimates of RMB Equilibrium Exchange Rate and Calculation of Real Exchange Rate Misalignment. Economic Research Journal, 12, 60-69.

Lu, F. (2006). Labour Productivity Growth in China and the International Comparison (1978-2004)-One of Long Term Researches on RMB Real Exchange Rate. China Center for Economic Research of Peking University, C2006004.

Ordóñez, J., \& Jusélius, K. (2009). The Balassa-Samuelson Effect and the Wage, Price and Unemployment Dynamics in Spain Transition to EMU membership. Economics: The Open-Access, Open-Assessment. E-Journal, 3, 1-30.

Samuelson, P. A. (1964). Theoretical Notes on Trade Problems. The Review of Economics and Statistics, 2, $145-$ 154.

Shi, J., \& Yu, H. (2005). Equilibrium and misalignment on RMB Exchange Rate: 1991-2004. Economic Research Journal, 4, 34-45.

Strauss, J. (1995). Real Exchange Rates, PPP and the Relative Price of Nontraded Goods. Southern Economic Journal, 991-1005.

Strauss, J. (1996). The Cointegrating Relationship between Productivity, Real Exchange Rates and Purchasing Power Parity. Journal of Macroeconomics, 2, 299-313.

Wang, C. (2006). Analysis of RMB Equilibrium Exchange Rate Based on the BEER Model. Journal of Central University of Finance \& Economics, 10, 39-41.

Wang, W. (2003). The Relative Labor Productivity Effect on the RMB Real Exchange Rate. Studies of International Finance, 8, 11-17.

Wang, W., \& Huang, W. (2005). Analysis on The RMB Behavioral Equilibrium Exchange Rate Model. Economic Science, 2, 48-57.

Xu, S. (2009). Research on RMB Equilibrium Exchange Rate Based on Montiel Theoretical Model. Commercial Research, 4, 186-188.

Yu, M. (2001). The Analysis of Balassa-samuelson Effect on the RMB Exchange Rate. Worl Economy, 5, 24-28.

Zhang, X. (1999). Theory and model of RMB equilibrium exchange rate. Economic Research Journal, 12, 7077.

Zhang, X. (2000). Balance and Unbalance: RMB rationality assessment from 1978 to 1999. Journal of Financial Research, 8, 13-24.

Zussman, A. (2001). A Purchasing Power Parity Paradox. Stanford Institute for Economic Policy Research Discussion Paper, 25.

\section{Note}

Note 1. In this empirical research, the real effective exchange rate of RMB replace RMB real exchange rate, if the index up, it means the appreciation of RMB, while the index down, it means the depreciation of RMB. 


\section{Copyrights}

Copyright for this article is retained by the author(s), with first publication rights granted to the journal.

This is an open-access article distributed under the terms and conditions of the Creative Commons Attribution license (http://creativecommons.org/licenses/by/3.0/). 